\title{
POWER OF POSSESSOR OF PERSONAL PROPERTY TO CREATE LIEN FOR REPAIRS AND STORAGE CHARGES SUPERIOR TO EXISTING INTERESTS OF OTHERS
}

\section{ROBERT E. LEE $\dagger$}

A repairman or warehouseman has a common-law lien on the property in his possession for repair and storage charges. A controversial question, which frequently arises, is: Do the liens of repairmen or warehousemen take precedence over the claims of prior chattel mortgagees, conditional sellers, or bailors of the property in question? For example, a person in possession of an automobile under a conditional sales contract authorizes a garageman to do repair work on the car. If the conditional buyer fails to maintain his payments under the conditional sales contract, may the conditional seller recover the possession from the unpaid garageman who has rendered services on the car?

The war has greatly increased the importance of the question, since it will probably be years before new automobiles can again be purchased on the market. The existing cars will in the meantime be continually in need of repairs. The automobile finance companies have already turned from the financing of automobile sales to the financing of repairs on automobiles.

\section{Conditional Sales and Chattel Mortgages}

The decisions of the various jurisdictions have differed widely on the question of priority as between the lien of an artisan for repairs and the lien or title of a conditional seller or chattel mortgagee previously secured. ${ }^{1}$ Both views are represented by respectable authority; each is supported by a variety of reasons. There probably cannot be

$\div$ B. S., I928, LL. B., I928, Wake Forest College; M. A., I929, Columbia University; LL. M., I935, S. J. D., I94I, Duke University. Member of North Carolina Bar. Assistant Professor of Business Law, Temple University. Secretary-treasurer of American Business Law Association. Author of Advanced Busrness LaW (I934) and coauthor of CASEs on ConTracts (I940). Contributor to legal periodicals.

I. For a discussion of this problem, see 5 BERRY, AUtOMOBIES (7th, ed. 1935) \$ 5.479 et seq.; Brown, Personal Property (I936) \& II2; (I927) 42 C. J., Motor Vehicles, \$ 453; HudDY, CYCLOPEDIA OF AUtOMOBILE LAW (9th ed. I932) §68; REstateMENT, SeCuRITY (I94I) \$\$ 75-76; I Seligman, EConomics of Installment Selling (1927) 64; Whiteside, Priorities Between Chattel Mortgagee or Conditional Seller and Subsequent Lienors (I925) Io CORN. L. Q 33I ; Note, Power of a Possessor of a Chattel to Impose a Lien Superior to Existing Interests (I927) 40 HARV. L. REv. 762; Note, Artisan's Liens Competing with Clains of Conditional Sale Vendor or Chattel Mortgagee (I923) 22 MICH. L. REv. 46; Note, Extent to Which Common-Law Artisan's Lien Has Been Supplanted by Statute (I938) 37 MICH. L. Rev. 273; (I922) 20 A. L. R. 49; (I924) 30 A. L. R. I227; (I928) 42 HARV. L. REV. I32; (I922) 5 MINN. L. Rev. 233; (I928) 76 U. of PA. L. ReV. 753 ; (I934) I2 TENN. L. ReV. 22I ; (I923) 32 Yale L. J. 623 ; (1926) 35 Yale L. J. 377. 
said to exist any general rule. The diversity may be largely attributed to the fact that many of the decisions have taken into consideration statutory provisions relating to artisans' liens. As is to be expected, the greater number of the cases have dealt with automobiles.

The cases subordinating the liens of artisans to the claims of prior chattel mortgagees and conditional sellers of the goods are usually based upon one or more of the following reasons:

I. Priority of liens is generally determined according to the time they attach to the property.

2. Property of a person is not generally taken without his consent to satisfy the debt of another.

3. One should not be compelled to pay for improvement to his property neither expressly nor impliedly contracted for or assented to.

4. If a conditional sale or chattel mortgage is recorded, the artisan can ascertain in advance the existence of an antecedent interest.

5. A priority granted to artisans will seriously impair financing by conditional sales or chattel mortgages and render these security instruments unsafe forms of doing business.

6. Specific provision in the conditional sale or chattel mortgage, restraining party in possession from authorizing repairs, is a controlling factor.

7. Express statutory provision, subordinating liens of artisans to claims of prior chattel mortgagees or conditional sellers, is a controlling factor.

The cases subordinating the claims of conditional sellers and chattel mortgagees to subsequent liens of artisans are usually based upon one or more of the following reasons:

I. The conditional sale or chattel mortgage expressly or impliedly authorized the person in possession to make necessary repairs.

2. The chattel was in the nature of an income-producing article and without repairs it would have been impossible to use it so as to pay the obligation owed the conditional seller or chattel mortgagee.

3. The repairs increased the value of the chattel and this inured to the benefit of the conditional seller or chattel mortgagee as well as the person in possession.

4. Specific provision in a conditional sale or chattel mortgage, requiring person in possession to keep chattel repaired, is a controlling factor.

5. Express statutory provision, subordinating the interests of prior chattel mortgagees and conditional sellers to liens of artisans, is a controlling factor. 
In the absence of an express statute subordinating the interest of the conditional seller or chattel mortgagee to the claims of a repairman, overwhelmingly the greater number of the cases that have favored the superiority of the repairman have based their decisions on an implied consent on the part of the encumbrancer.

Courts have, at times, seized upon the slightest circumstance as a basis for the implication of consent. In a few states a mortgagee or conditional seller by allowing the mortgagor or conditional buyer to have possession of a chattel for use is regarded as having impliedly consented to a contract for reasonable repairs. ${ }^{2}$ In Meyers v. Neely and Ensor Auto Co., ${ }^{3}$ a Maryland case, though the conditional sale was recorded, yet because the conditional buyer was permitted to have exclusive possession and use of the automobile, the conditional seller was deemed to have impliedly authorized the conditional buyer to proceed to create a lien for necessary repairs. The court reasoned that the need for repairs was an inevitable incident of the use for which the automobile was purchased. And again, in Grusin v. Stutz Motor Car Co. of America, ${ }^{4}$ an Indiana case, an automobile was sold to a purchaser under a duly recorded chattel mortgage. Without consent or knowledge of the mortgagee, the mortgagor placed the automobile in the hands of a garageman for repairs. The repair bill was $\$ 936.62$. The balance due to the mortgagee on the car at the time was $\$ 523$. Holding that the rights of the repairman were paramount to those of the mortgagee, the court said that the authority of the mortgagor to act on behalf of the mortgagee was implied from the circumstances. The court reasoned that the mortgagee must have contemplated that the car would be used and that necessary repairs would be required, and that this constituted the mortgagor the agent of the mortgagee for the purpose of creating a lien for repairs. There was in the recorded chattel mortgage contract an express provision to the effect that the mortgagor was to pay the expense of repairs. But the court said: "When the mortgagor, acting for himself and as the agent of the mortgagee, delivers the mortgaged property and authorizes the making of repairs or the furnishing of materials and supplies therefor, a contract arises between the mortgagor and the mortgagee on the one hand, and the mechanic or artisan or the other, and the law creates a lien in

2. New Britain Real Estate and Title Co. v. Collington, Ioz Conn. 652, I29 Atl. 780 (I925); Grusin v. Stutz Motor Car Co. of America, 206 Ind. 296, I87 N. E. 382 (1933) ; Meyers v. Neeley \& Ensor Auto Co., I43 Md. I07, I2I Ati. gr6 (r923); Stebbins v. Balfour, I57 Minn. I35, I95 N. W. 773 (I923) ; Johnson v. Yates, I83 N.' C. 24, IIo S. E. 603 (I922) (chattel mortgage construing statute affirming C. I. Doctrine); Gen. Motor Co. v. Securities Inv. Co., I6 Tenn. App. 608,65 S. W. (2d) 590 (I933); Guaranty Securities Corp. v. Brophy, 243 Mass. 597, 147 N. E. 751 (I923); Wingote v. Miss. Securities Co., I52 Miss. 852, 120 So. 175 (I929).

3. I43 Md. 107, I2I At1. 916 (I923).

4. 206 Ind. 296,187 N. E. 382 (I933). 
favor of the latter which will bind the property, notwithstanding an additional agreement between the mortgagor and the mortgagee that the mortgagee shall pay for the repairs, or even an agreement that no liens shall be incurred, since the law creates the lien and not the consent of the parties."

In the above cases it does not appear that the automobiles were to be used for the purpose of earning money with which to pay the purchase-price. This circumstance has influenced some of the decisions. ${ }^{5}$ In the leading English case of Williams $v$. Allsup, ${ }^{6}$ wherein a shipwright's lien for repairs to a vessel was held superior to the interests of a mortgagee, Erle, C. J., said : "I put my decision on the ground suggested by Mr. Millish, viz., that the mortgagee having allowed the mortgagor to continue in the apparent ownership of the vessel, making it a source of profit and a means of earning the wherewithal to pay off the mortgage debt, the relation so created by implication entitles the mortgagor to do all that may be necessary to keep her in an efficient state for that purpose. The case states that the vessel had been condemned as unseaworthy by the government surveyor, and so was in a condition to be utterly unable to earn freight or be an available security or any source of profit at all." 7 In Metropolitan Securities Co. $v$. Orlow, 8 Marshall, C. J., of the Ohio Supreme Court, concedes the paramount claims of a mechanic when asserted against a chattel such as a locomotive in public use, but denies the same claim when asserted against a pleasure car. The distinction is made on the ground that a pleasure car not only earns nothing, but offers greater security to the mortgagee by remaining idle. The doctrine announced in Williams $v$. Allsup, it is submitted, is difficult of application to the facts of a particular case. It should be limited to admiralty cases. When is a chattel purchased under a title-retaining instrument to be deemed an incomeproducing article? Would it be profitable to repair and put in running condition certain types of income-producing machines? Would not the costs of repairs offset any profits that might be derived from a continued use of the chattels? And also, may not a chattel be used for both pleasure and business?

In Goldstein v. Mack Motor Truck Co., ${ }^{9}$ a Rhode Island case, $A$ gave $B$ in Massachusetts a truck under a conditional sales contract. There was a provision in the contract to the effect that $B$ was to keep

5. Watts v. Sweeney, I27 Ind. II6, 26 N. E. 680 (I890) (mortgaged railway locomotive); Hammond v. Danielson, I26 Mass. 294 (1879) (mortgaged hack driven for hire); Garr v. Clements, 4 N. D. 559,62 N. W. 640 (I895) (mortgaged threshing machine).

6. Io C. B. N. S. 4 I7 (Eng. I86I).

7. Id. at 426 .

8. I07 Ohio St. 583, I40 N. E. 306 (1923).

9. 56 R. I. I, I83 Atl. I36 (I936). 
the truck in repair at his own expense. $B$ defaulted in monthly payments. $A$ found the truck in the possession of $C$, a repairman, in Rhode Island, a state where conditional sales are not required to be filed. $B$ had authorized the repairs. In an action of replevin, the Rhode Island court held that $A$ was entitled to possession of the truck and nominal damages. A similar set of facts and decision were present in an Illinois case ${ }^{10}$ dealing with a truck sold under a chattel mortgage contract.

In both the Rhode Island and the Illinois case the chattel was a truck, and it was doubtless the understanding of the parties that the truck would be profitably employed, so as to produce an income with which to pay the purchase-price. The courts might have very well invoked the doctrine of Williams $v$. Allsup. Trucks are income producing chattels. It is true that the title-retaining instruments expressly denied to the party in possession any authority to subject the chattel to a lien, but could not the decision have been grounded upon an apparent authority? Secret limitations of authority do not affect the rights of innocent third persons who rely upon an apparent authority. ${ }^{11}$ It is far more logical to imply an authority to create repair liens on trucks than on passenger cars.

It is generally held, however, that a chattel mortgage or conditional sales contract containing an express provision requiring the person in possession to keep the chattel in repair, at his own expense, is sufficient to protect the chattel mortgagee or conditional seller against the liens of repairmen. ${ }^{12}$ If the provision merely states that the mortgagor or conditional buyer is to keep the chattel in repairs, and is silent on the question of who is to bear the expense of the repairs, there is some uncertainty as to the resilt that will be reached. It is probable that the court will grasp this as a circumstance implying an authority on the part of the mortgagor or conditional buyer to authorize a lien for repairs on the credit of the automobile. ${ }^{13}$ On the other hand, it may

Io. Ehrlich v. Chapple, 3II I11. 467 , I43 N. E. 6I (I924).

II. In Albemarle Supply Co. v. Hend \& Co., I K. B. 307 (Ig28), $A$ delivered to $B$ taxicabs under a hire-purchase agreement, which expressly stipulated that $B$ was to keep them in repair and not to subject them to any liens. $B$ delivered the cabs to $C$ to be repaired. $C$ knew at the time that $B$ held the cabs under a hire-purchase agreement, but was ignorant of the terms. $B$ defaulted in his payments to $A$ while the the cabs were in the possession of $C . A$ terminated his agreement with $B$ and demanded the cabs from $C$. $C$ claimed a common-law lien for repairs and refused to surrender cabs. $A$ brought an action of detinue. The court held that $C$ had a valid lien against the property.

I2. Ehrlich v. Chapple, 3II I1l. 467, I43 N. E. 6I (I924), II VA. L. REV. 67 ; Metropolitan Securities Co. v. Orlow, I07 Ohio St. 583, I40 N. E. 306 (I923); Goldstein v. Mack Truck Co., 56 R. I. I, I83 Atl. I36 (I936); Overland Auto Co. v. Findley, 234 S. W. 106 (Tex. Civ. App. I92I). Contra: Grusin v. Stutz Motor Car Co. of America, 206 Ind. 296, I87 N. E. 382 (1933).

I3. See Restatement, Security (I94I) \& 76, comment. In Atlas Securities Co. v. Grove, 79 Ind. App. I44, I37 N. E. 570 (I922), the conditional sale contract required the conditional buyer "to make all repairs necessary to keep the property in first-class 
be very well argued that such an express stipulation implies quite definitely that the expense of repairs is to be paid by the chattel mortgagor or conditional buyer, and that this is more in keeping with general custom.

A considerable number of cases have rejected the implied consent theory and emphatically declared that a lien cannot attach to property without "due authority" of the owner. ${ }^{14}$ In speaking of the implied consent theory, a Rhode Island court ${ }^{15}$ said, "The implication of authority and consent will not arise solely from the fact that a mortgagor or vendee is permitted to retain possession and to use a chattel which in the course of its use will probably need repairs." Williston says that a conditional "seller's title prevails over an asserted lien of one who makes repairs on the order of the conditional buyer." 16

A similar rule exists generally in respect to mechanics' liens for repairs or improvements to real property. As a general rule, where real property is subject to an existing mortgage or other encumbrance, such mortgage or encumbrance retains its priority and the mechanic's lien is postponed thereto, notwithstanding the value of the security is increased by the labor and materials of the mechanic's lien claimant. ${ }^{17}$ The mortgagor may, of course, create a mechanic's lien affecting his own interest. A purchase-money mortgage on real property has many of the characteristics of a chattel mortgage and a conditional sale.

In a few cases the court has denied the lien of the repairman on personalty even though the repairs where made with the knowledge of the owner. ${ }^{18}$ In Arnold v. Chandler, ${ }^{19}$ the plaintiff delivered to Ruzzo

condition." The court said (Id. at I5I, I37 N. E. at 573) : "The mere fact that the automobile in the instant case needed repairs in order that the vendee might continue to use it is not sufficient to give appellee (repairman) a priority over title of appellant (conditional seller). The intent of the vendors, however, to permit and authorize necessary repairs to be made by the conditional vendor appears in the contract itself."

I4. Ellis Motor Co. v. Hibbler, 219 Ala. 53, I2I So. 47 (I929); Hawkes v. First Nat'l Bank of Telluride, 75 Colo. 47, 224 Pac. 224 (I924); Baughman Auto Co. v. Emanuel, I37 Ga. 354, 73 S. E. 5II (I9I2) ; Ehrlich v. Chapple, 3 II I1l. 467, I 43 N. E. 6I (I924) ; Storms v. Smith, 137 Mass. 20I (I884); Bath Motor Mart v. Miller, I22 Me. 29, II8 Atl. 7 I5 (I920); Denison v. Shuler, 47 Mich. 598, II N. W. 402 (I882); Sargent v. Usher, 55 N. H. 287 (1875) (agister's lien subordinate to the lien of chatteí mortgagee); General Motors Acceptance Corp. v. Sutherland, I22 Neb. 720, 24I N. W. $28 \mathrm{I}$ (I932); Cleveland Auto Top and Trimming Co. v. American Finance Co., I24 Ohio St. I69, I77 N. E. 2I7 (I93I); Cache Auto Co. v. Central Garage, 63 Utah Io, 22I Pac. 862 (I923); Arnold v. Chandler, 45 R. I. 469, 123 Atl. 85 (I924); Revere Copper \& Brass, Inc., v. Craig, 52 R. I. I06, I57 At1. 879 (I932) ; Scott v. Garage Co., 88 W. Va. 92, 105 S. E. 425 (I92I); Adler v. Godfrey, I53 Wis. I86, 140 N. W. III5 (IgI3) (garage keeper's lien for storage); see Brown, Personal Property (I936) \$1I2; (1938) \& C. J. S., Bailments, \$35h; 3 Jones, Chatrel Mortgages and CondIIONAL SALES (6th ed. r933) § rrz2; (I933) I2 TENN. L. Rev. 22 I.

I5. Arnold v. Chandler, 45 R. I. 469, 472, I23 At1. 85, 86 (I924).

I6. I WILliston, SALES (2d ed. I924) \& 324.

I7. 2 JONES, LIENS (3d ed. I9I4) \$\$ I458-I459; I JoNes, MORTGages (8th ed. I928) $\$ \$ 588,603$; 36 Ans. JUR., Mechanics Liens (I94I) § I8I; (Ig26) 40 C. J., Mechanics' Liens, \$ 369 .

I8. Baughman Auto Co. v. Emanuel, I37 Ga. 354, 73 S. E. 5II (I9I2) ; Arnold v.

Chandler, 45 R. I. 469 , I23 Atl. 85 (I924).

19. 45 R. I. 469 , I23 Atl. 85 (1924). 
an automobile under a bailment lease, designated by the Rhode Island courts a conditional sale. Ruzzo placed the car in the hands of the defendant for necessary repairs. When Ruzzo defaulted in his monthly payments, the plaintiff demanded the automobile of the defendant. Upon the defendant's refusal to give it up until his repair charges were paid, plaintiff brought an action of replevin. Held, plaintiff was entitled to possession of automobile, notwithstanding the fact that Ruzzo was allowed to remain in possession of the car as conditional buyer and plaintiff knew repairs were being made. The court rejected the contention of defendant that the plaintiff by entrusting Ruzzo with possession, with knowledge that it would be in need of repairs, gave him an implied authority to create a lien against it. The court declared that possession, under such circumstances, did not raise an implication of authority.

The conduct of the conditional seller was not sufficient to have estopped him from denying the authority of the conditional buyer to order the repairs. A conditional seller may reasonably assume that repairs are being made solely on the personal credit of the conditional buyer and not upon the credit of the property itself.

It seems to make little difference with the courts that have liberally and indiscriminately followed the implied consent doctrine whether the chattel mortgage or conditional sales recording statutes have been complied with. There have been several cases where the conditional seller's interest in a recorded conditional sale has been subordinated to the claims of a repairman on the broad principle that possession and use of a chattel alone imply an authority to create repair liens. ${ }^{20}$ In the greater number of cases, however, a mortgagee or conditional seller who has duly recorded the agreement will prevail over a repairman who has made repairs at the request of a mortgagor or conditional buyer. ${ }^{21}$ The same result has been reached in states where conditional sales are not required to be recorded..$^{22}$

The chattel mortgage and conditional sale recording statutes vary materially as to the classes of persons they are intended to protect. Some statutes protect all "third parties," while others protect only innocent purchasers from, or judgment and attachment creditors of, the person in possession. Section 5 of the Uniform Conditional Sales Act reads: "Every provision in a conditional sale reserving property in the

20. New Britain Real Estate and Title Co. v. Collington, I02 Conn. 652, I29 Atl. 780 (rg25); Meyers v. Neeley \& Ensor Auto Co,, I43 Md. 107, I2I Atl. 916 (I923).

2I. Metropolitan Securities Co. v. Orlow, I07 Ohio St. 583, I40 N. E. 306 (1923); Ford v. Bates, 150 Ore. 672, 47 P. (2d) 95I (I935); 3 Jones, ChatTer MorTGages ANd Conditional Sales (6th ed. I933) \& II22; Whiteside, Priorities Between Chattel Mortgagee or Conditional Seller and Subsequent Lienors (I925) Io CoRN. L. Q. 33 I [Fryer, Readings on Personal Property (I938) 4I7].

22. Hoist \& Derrick Co. v. Lynn, I67 Miss. 93, I48 So. 35I (1933); Restatement, SECURITY (I94I) $\$ 76$, comment. 
seller, shall be void as to any purchaser from or creditor of the buyer, who, without notice of such provision, purchases the goods or acquires by attachment or levy a lien upon them, before the contract or copy thereof shall be filed as hereinafter provided, unless such contract or copy is filed within ten days after making of the conditional sale."

Only innocent purchasers from and creditors of the conditional buyer are entitled to attack the agreement if it has not been filed. The Act uses the phrase "purchaser without notice," but this undoubtedly is the equivalent of "bona fide purchaser" or "innocent purchaser." The creditors are those who have acquired a lien on the property by way of attachment or levy prior to the filing and without notice that the buyer held the goods under a conditional sales contract. Since repairmen are neither purchasers nor creditors who have acquired a lien by attachment or levy, it would seem that in the states that have adopted the Act a conditional sales contract does not have to be filed as far as repairmen dealing with conditional buyers are concerned. The conditional seller of an unfiled contract should be allowed, accordingly, to take his property from the possession of a repairman. The conditional sales transaction is not to be considered as fraudulent on account of the deceptive appearance of ownership in the buyer. Section 4 of the Act establishes the conditional sale transaction, as follows: "Every provision in a conditional sale reserving property in the seller after possession of the goods is delivered to the buyer, shall be valid as to all persons, except as hereinafter otherwise provided."

It is questionable whether the chattel mortgage or conditional sale recording statutes should in any way affect the rights of a repairman. An owner who has authorized another to create a lien on his property should be estopped from claiming the protection of any recording statute. A rule that requires a repairman to search the chattel mortgage and conditional sale recording statutes prior to the doing of any repairs would work a tremendous hardship upon repairmen. A repairman would have to either demand costs in advance (something that cannot always be determined in advance) or at great inconvenience to himself and the person in possession search the records for either a chattel mortgage or conditional sale. The burden would be far greater to a mechanic than to a purchaser from, or creditor of, the party in possession. Sales and execution proceedings usually are not required to be carried through with the speed of repairs; for example, repairs to an automobile.

The Uniform Conditional Sales Act, adopted by nine states, ${ }^{23}$ has no provisions relating to liens of artisans and repairmen. The Uni-

23. Arizona, Delaware, Indiana, New Jersey, New York, Pennsylvania, South Dakota, West Virginia and Wisconsin. 2 U. L. A. (Supp. I94I) 6. 
form Chattel Mortgage Act, as yet not adopted by any of the states, ${ }^{24}$ provides as follows: ${ }^{25}$

"I. (a) Chattel liens given by any statute or rule of law against an owner of goods for services or materials necessary to the protection or preservation of the goods, shall attach against the interest of the mortgagee, although the instrument be duly filed or the lienor have notice of the mortgage.

"I. (b) Chattel liens so given shall likewise attach against the interest of the mortgagee, to the extent that such services or materials result in direct enhancement of the value of the goods.

"2. Such liens shall not so attach, however, beyond twentyfive percent of the original amount secured by the mortgage.

"3. Failure by the mortgagor to dissolve any such lien within ten days after notice of demand duly given by the mortgagee, shall constitute default; and the mortgage may provide that sub-. jection of the goods to any such lien shall constitute default.

"4. This section shall not of itself obligate the mortgagee personally for the debt secured by any such lien; nor shall consent of the mortgagee to the attachment of a more extended lien be construed of itself to make the mortgagee so liable.

"5. Subsection $x$ shall, with respect to the lien of garagemen on mortgaged automobiles, extend only to amounts not exceeding fifty dollars."

The Restatement of Security ${ }^{26}$ reads:

"Subject to the provisions of recording statutes, where a lien exists in consequence of the bailment of a mortgaged chattel or a chattel held under a conditional sales contract, the interest of the mortgagee or conditional vendor is prior to that of. any lienor except a hotelkeeper, a landlord or a connecting carrier unless words or circumstances justify the inference that the mortgagee or conditional vendor has consented to subordinate his interest." A comment on the above section says :

"Normally the priority of legal interests is determined by the order of their creation. While subsequent legal interests sometimes prevail over prior interests because the holders of the prior interests have created or permitted situations likely to deceive holders of subsequent interests who acquire the subsequent interests in good faith and for value, the requirements of public recordation in the case of conditional sales and chattel mortgages almost universally assure that the holders of subsequent interests can ascertain in advance the existence of the antecedent interests."

Lien statutes are more and more becoming the decisive factors in contests for priority between repairmen and conditional sellers or chattel

24. Fryer, Readings on Personal. Property (3d ed. I938) 434.

25. Ibid. Found also in Sturges, Cases and Materials on Credit Transactions (2d ed. 1936) 103I.

26. Restatedent, Security (I94I) §76. 
mortgagees. ${ }^{27}$ The common-law artisan's lien has been replaced by statute in some particular in all but five states. ${ }^{28}$ The language of these statutes is exceedingly varied in the several jurisdictions. Amendments are frequent and the courts widely differ on their interpretations. Anything other than a general reference to these statutory provisions, therefore, would do no more than complicate an already difficult subject by adding a mass of unrelated detail.

In many states the statutes are merely declaratory of the common law and do nothing more than provide an effective means of enforcing the artisan's lien. ${ }^{29}$ But in some jurisdictions statutes contain express provisions upon the question of priority as between repairmen and other lien claimants. In several instances the statutes have specifically declared the artisan's lien superior to the liens of conditional sellers or chattel mortgagees. ${ }^{30}$ In New York, ${ }^{31}$ for example, the statute provides that the artisan's lien may arise "at the request or with the consent of the owner, whether such owner be a conditional vendee or a mortgagor remaining in possession or otherwise." California, ${ }^{32} \mathrm{New}$ Mexico, ${ }^{33}$ North Carolina, ${ }^{34}$ South Dakota ${ }^{35}$ and Wisconsin ${ }^{36}$ allow the lien when the repairs are rendered "at the request of the owner or legal possessor." In Virginia ${ }^{37}$ the "person legally in possession" may create an artisan's lien superior to a prior conditional sale or chattel

27. 3 Jones, Chatter Mortgages and Conditional Sales (6th ed. r933) § Iiz4; Whiteside, Priorities Between Chattel Mortgagee or Conditional Seller and Subsequent Lienors (I925) Io CoRN. L. Q. 33I; Note, Extent to Which Common-Law Artisan's Lien Has Been Supplanted by Statute (I93S) 37 MrCE. L. REv. 273.

28. Ibid.

29. At common law the only means available to an artisan for the enforcement of his lien was a retention of the property until the repairs were paid. He had no right to sell the subject matter of the lien. Statutory provisions for enforcing the liens vary, but in most states the repairman after a specified time and notice to the owner may sell the property at a public or private sale. Note, Extent to Which Common-Law Artisan's Lien. Has Been Supplanted by Statute (1938) 37 MICH. L. REv. 273, 274; (I938) 8 C. J. S., Bailments, \& 35e.

30. Cal. Civ. Code (Deering, I93I) \$§ 305I-3052; ME. Rev. Stat. (1930) c. 105, § 56; MrnN. Stat. ANN. (Mason, I927) § 8528; NEw MEx. STAT. ANN. (Courtright, I929) $\$ 82-402 ; N$. Y. CoNs. Laws (McKinney, Supp. 1939) c. 33, § I84; ORE CODE ANN. (Bobbs-Merrill, I930) §§ 5I-50I, 5I-504; S. D. CoMP. LAwS (I929) § I700-A; WIS. STAT. (I939) \$289.4I ; VA. CODE ANN. (Michie, I936) \$6443 (to extent of \$25) ; Commercial Credit Corp. v. Maskowitz, I42 Misc. 773, 255 N. Y. Supp. 525 (I932), aff'd, 238 App. Div. 831, 262 N. Y. Supp. 973 (I933), reargumtent denied, 239 App. Div. 770, 263 N. Y. Supp. 936 (I933); I JoNES, LIENS (3d ed. I914) \$\$ 73I-786c; Restatenent, Security (I94I) \& 76, comment; Note (I92I) 6 MinN. L. ReV. 233.

In New Jersey repairs on aircraft are superior to properiy recorded prior conditional sales and chattel mortgages, but repairs on motor vehicles are subordinate to properly recorder prior conditional sales and chattel mortgages. N. J. REv. STAT. (I937) $\$ 2: 60-2$ (aircraft) and $\$ \$ 2: 60-21,2: 60-22$ (motor vehicles).

3I. N. Y. CoNs. LAws (McKinney, Supp. I939) c. 33, § 184. Minnesóta has a similar provision. MinN. Stat. AnN. (Mason, I927) \$ 8528 .

32. CAL. CIV. CODE (Deering, I93I) \$\$ 305I-3052.

33. New Mex. Stat. AnN. (rg29) \$ 82-40I.

34. N. C. CODE ANN. (Michie, I935) §2435.

35. S. D. CoMp. LAwS (I929) \$ I700-A.

36. WIS. Stat. (I939) c. I43, \$289.4I.

37. VA. CODE ANN. (Michie, I936) \$6443. 
mortgage to the extent of twenty-five dollars only. In Oregon "at the request of its owner, reputed owner, or authorized agent of the owner, or lawful possessor thereof."

In Illinois, ${ }^{39}$ Iowa, ${ }^{40}$ Maryland, ${ }^{41}$ New Jersey, ${ }^{42}$ and Washington ${ }^{43}$ statutes expressly subordinate the lien of the artisan to conditional sales, chattel mortgages, and other prior liens of record. Prior encumbrances not on record are, of course, inferior in these states to the artisan's lien.

At common law the repairman has a lien only so long as he retains possession of the property upon which the work has been done. ${ }^{44}$ The artisan's lien is lost by a voluntary surrender of possession. Statutes, however, in a considerable number of states expressly provide that the lien is not dependent upon a retention of possession by the artisan. ${ }^{45}$ To be entitled to a lien after parting with possession, a majority of these statutes require a filing of a notice of the lien, within a specified time, usually thirty or sixty days, after which foreclosure takes place as in the case of chattel mortgages. ${ }^{46}$

In states where by statute or decision an artisan's lien has been subordinated to existing liens of conditional sellers and chattel mortgagees, these statutes, providing for enforcement of an artisan's lien

38. ORE. CODE ANn. (Bobbs-Merrill, r930) §5I-50I.

39. ILL. STAT. ANN. (Smith-Hurd, I935) c. 82, \$ 43 (statute mentions only recorded chattel mortgages).

40. IOWA CODE (1939) c. $456, \S$ 10343.

4I. MD. CoDE ANN. (Flack, r939) art. 63, § 4I.

42. In New Jersey a garage keeper's lien for repairs and storage is expressly subordinated to a properly recorded prior conditional sale or chattel mortgage; but one who does repairs on, or furnishes storage for, an aircraft is granted a lien "that shall be superior to all other liens, except liens of state, county or city for taxes, and the operator of such aircraft shall be deemed the agent of any owner, mortgagee, conditional vendor or other lienor thereof for the creation of such superior lien." There is no statute determining the priority of those that furnish repairs and storage for other kinds of personal property. N. J. REv. STAT. (I937) \$\$2:60-2I, 2:60-22 (motor vehicles) and $\$ 2: 60-2$ (aircraft).

43. Wast. Rev. Stat. ANN. (Remington, I932) § II56.

44. Brown, Personal Property (I936) \$ I08; (I938) 8 C. J. S., Bailments, § 35 ; ScotT, Batlments (I93I) I09; Rodgers v. Grothe, $58 \mathrm{~Pa}$. 4I4 (I868).

45. Ala. Code (1928) \$\$ 8863-8864; ARK. DIG. STAT. (Pope, I937) $\$ 8820-8827$; GA. CoDE (I933) $\$ \$ 67-2003,67-2401$; Fla. CoMp. LAwS (I927) $\$ \$ 5360,5382,5384$; Irl. Stat. AnN. (Smith-Hurd, I935) c. 82, §40; Kan. Stat. ANN. (Corrick, I935) \$ 58-201; KY. Stat. ANN. (Carroll, I936) art. 5, \$ 2739 h-I (p. I447); MD. CodE ANN. (Flack, I939) art. 63, \$ 4I (lien on motor vehicles; valid against owner and third persons without notice); ME. REv. STAT. (I930) c. I05, \$\$ 66-70; NEB. CoMp. STAT. (I929) $\$ \$ 52-20 I$ to $52-203 ; N$. J. REv. STAT. (1937) \$2:60-22 (motor vehicles) and $\$ 2: 60-3$ (aircraft); N. M. Stat. ANN. (1929) \$ 82-ror et seq.; N. D. CoMp. Laws (I9I3) \$\$6877-6878; ORLA. STAT. (I93I) \$\$ IIOOI-IIO04; ORE. CoDE ANN. (I930) \$\$ 5I-50I to 5I-506; S. D. CoMP. LAWS (I929) \$\$ I700A-I700E; WASE. REv. STAT. ANN. (Remington, I932) \$\$ II 54-II 57; Note, Extent to Which Common-Laze Artisan's Lien Has Been Supplanted by Statute (I938) 37 Mrcr. L. Rev. 273, 275.

46. GA. CODE (I933) \$\$ 67-2003, 67-240I ; ILL. STAT. ANN. (Smith-Hurd, I935) c. $82, \S 45$; Kan. STAT. ANN. (Corrick, I935) art. 58, \$ 201 ; Ky. Stat. AnN. (Carroll, I936) art. 5, \$2739I (p. I447); NEB. CoMp. Stat. (I929) \$\$ 52-20I to 52-203; N. D. COMP. LawS (I9I3) $\$ \$ 6877-6878$; OKLA. StaT. (I93I) \$\$ IIOOI-IIO04; ORE. Code ANN. (I930) $\S 5$ I-5OI to 5I-506; S. D. CoMP. LAWS (I929) §§ I700A-I700E; WASH. REv. STAat. ANN. (Remington, I932) §\$ II54-II57. 
after parting with possession, present no particularly difficult problem. On the other hand, if in states where these statutes exist there are decisions or other statutes declaring an artisan's lien superior to liens of conditional sellers and chattel mortgagees, the artisan who has parted with possession has precedence over a prior encumbrancer who has parted with possession. This is a clear violation of the general rule that a lien takes precedence accordance to the time it attached to the property. Both the repairman and the prior encumbrancer are lien claimants who have voluntarily surrendered possession of a chattel. Both may have satisfied statutes requiring a public record of their lien. It would seem that the claim of the first encumbrancer should be preferred, in the absence of circumstances indicating that the conditional seller or chattel mortgagee has consented to a subordination of his interest. But the law is otherwise, of course, in those states where there is a manifested legislative intent that the artisan's lien shall be superior to the existing liens of conditional sellers and chattel mortgagees. The statute, and not the contract of the party in possession, creates the lien.

The different types of statutory liens mentioned above are generally broad enough to include repairs on all kinds of personal property; but there are a few that are limited explicitly to a designated species of property. An increasing number of these statutes are applicable only to motor vehicles.

At common law a garage keeper is not accorded a lien for storage charges. ${ }^{47}$ This is due to the fact that the privilege of a lien is usually extended only to those who have by their skill and labor imparted some additional value to the property. The lien, however, has today been granted in many states by statute. ${ }^{48}$ In several of these states the lien exists even though the garage keeper voluntarily surrenders possession. ${ }^{49}$

47. Brown, Personal Property (1936) \& io8; Note (I938) 37 Mich. L. Rev. 273, 277; see (I9I6) 6 C. J. II32, notes $97-98$ and (I938) 8 C. J. S. 292, note 72 for cases.

48. ARIz. Rev. CoDe (I928) § 2042; CAL. CIV. CODE (Deering, I937) \$ 3051-7; DeI. REv. Code (I935) \$\$ 3344-3350; IND. Stat. ANN. (Baldwin, I935) \& III85; Iowa Code (I939) § I0345; Ky. Stat. (Carroll, 1930) \$2739h-I, 2; Mass. Gen. LAws (1932) c. 255, \$25; ME Rev. STAT. (1930) c. 105, \$\$ 56, 57; Mo. REv. STAT. (I929) \$32I8; NEv. CoMp. LAWS (Ig29) \$3772; N. H. PUB. LAWs (Ig26) c. 217, \$\$ 35, 36; N. J. Rev. Stat. (I937) \$\$ 2:60-20 to $2: 60-31$; N. Y. Cons. LAWS (I909) c. $38, \$ 184$ (Birdseye, I9I7, p. 4930); (McKinney, I9I7, tit. 32); TENN. CODE (I932) \$ 7979; VA. Code (1936) §6445; W. VA. Code ANN. (1936) § 2936 ; WIS. STAT. (1939) \& 289.43.

In the following states artisans or bailees generally are given a lien for storage. Accordingly, garage owners in these states possess liens for storage.

CaL. Civ. Code (Deering, I937) \$\$305I, 3052; MInN. STat. (Mason, I927) $\$ \$ 8507-8509$; MONT. REV. CODE (I935) \$\$ 8383-8385; N. D. CoMP. LAWS (I9I3) $\$ \$ 6877-6878$; OKLA. STAT. (I93I) \$ I0985; Ill. REv. STAT. (Smith-Hurd, I937) c. 82, $\$ \$ 40-45$; ORE. CODE ANN. (I930) \$\$ 5I-5OI to 5I-506. Oregon.

49. Delaware, Illinois, Maryland, Nevada, New Jersey, Maine, Missouri, and 


\section{Pennsylvania Bailment Leases}

A bailment lease with an option to buy attached is valid in Pennsylvania, though unrecorded, against all persons. ${ }^{50}$ In this state the artisan's lien is the same as at common law, except that a more effective means of enforcement has been provided by statute. ${ }^{51}$ There are no statutory provisions in Pennsylvania relating to the question of priority as between liens of an artisan and prior encumbrance. The artisan loses his lien through a voluntary possession to the owner. ${ }^{52}$ Garage keepers in Pennsylvania have been given no statutory lien for storage charges.

In Pennsylvania, the courts have definitely subordinated the favored position of the repairman and warehouseman to that of the bailor. ${ }^{53}$ The bailor is permitted, upon breach of the terms of the bailment lease, to recover the property wherever it may be found, even though it may be in the hands of an innocent person with bona fide claims for repair or storage charges.

The doctrine as to trademan's or artisan's liens was succinctly stated by the Supreme Court in Meyers and Bro. v. Bratespiece: ${ }^{54}$ "Whenever a workman or artisan by his labor or skill increases the value of personal property placed in his possession to be improved he has a a lien upon it for his proper charges until paid,' but, 'in order to charge a chattel with this lien, the labor for which the lien is claimed must have been done at the request of the owner or under circumstances from which his assent can be reasonably implied. It does not extend to one not in privity with the owners."

In Stern $v$. Sica ${ }^{55}$ an automobile was delivered under a bailment lease contract which provided that the automobile should be returned "in as good condition" as when delivered. The car was found, after default in rental payments, in the possession of a repairman. The Superior Court held that the repairman could not withhold possession

50. General Motors Acceptance Corp. v. Hartman, II4 Pa. Super. 544, I74 Atl 795 (I934); Stern \& Co. v. Paul, $96 \mathrm{~Pa}$. Super. II2 (1928).

5I. Act of May 7, I925, P. L. 557, PA. STAT. AnN. (Purdon, 1930) tit. 6, §§ II-I4.

52. ScotT, Law of BaILMents in PeNNSylvania (I93I) rog.

53. Meyers \& Bro. v. Bratespiece, I74 Pa. II9, 34 Atl. 55I (I896); Leitch v. Sanford Motor Truck Co., 279 Pa. 160, I23 At1. 658 (I924) ; Estey Co. v. Dick, 4 I Pa. Super. 6ro (I9I0); Stern v. Sica, 66 Pa. Super. 84 (I9I7); Hecht v. Valkone Dye \& Finishing Works, $66 \mathrm{~Pa}$. Super. 97 (I9I7); Bankers' Commercial Security Co. v. Brennan and Levy, 75 Pa. Super. I99 (I920) ; Sears, Roebuck \& Co. v. White, 3 D. \& C. 338 (Pa. I923); Frazier v. Bell \& Dunie, 39 Lanc. 529 (Pa. I925) ; Edson \& Co. v. Rinker \& Anderson, 20 Berks 8I (Pa. 1926); F. A. North \& Co. v. Hall, 20 Del. 324 (Pa. I928); Conrad v. Hoch, 44 York I32, 26 Luz. 3, I4 D. \& C. I72. (Pa. I929); Commercial Banking Corp. v. Warner, 3 I Lack. 68 ( $\mathrm{Pa}$. I930); Commercial Credit Co. v. Wilson, I2 Erie I29 (Pa. I930); Equitable Automobile Finance Co. v. Manuel, I6 D. \& C. 812 (Pa. I032); Equitable Credit Co. v. Lloyd's Garage, 21 D. \& C. 270 (Pa. I934); cf. Auto Security Co. v. Mickens, 80 Pa. Super. 462 (I9z3); 5 Berry, AutoMIOBILES (7th ed. I935) \& 5.579 et seq.

54. I74 Pa. II9, I2I, 34 At1. 55I (I896).

55. $66 \mathrm{~Pa}$. Super. 84 (IgI7). 
from the bailor until the repair charges were paid. "There is nothing in the language of the lease, nor any inference from the language used, which would support any authority in the bailee to impair the bailor's title by handing the property to a repairman, who imposes a lien thereon. The use of the car cannot be made the foundation for authority to subject the property to a lien: there should be more definite evidence of authority coming from the owner. It may arise by implication but the facts from which the inference is to be drawn should be such as to reasonably lead to but one conclusion. The legal relation of lessor and lessee of personal property would take on an aspect not thought of by the parties of the bailee could create a lien for repair charges against the property, of which the owner would have no knowledge, and could in no way control." 56

In Estey Co. v. Dick ${ }^{57}$ the bailee secretly and against the terms of the lease placed a piano in an incorporated storage warehouse under a fictitious name. Several months later the bailor discovered the whereabouts of the piano and brought an action of replevin to recover its possession. The warehouse company refused to return the piano unless the storage charges were paid, alleging that since it was an incorporated storage company it was bound to receive without discrimination, like a common carrier, the goods of all who offer them, and therefore it acquired a lien for storage charges even as against the demand of the real owner. In ruling against the warehouse company, the Superior Court said: "We are led then to inquire to what extent the courts of this country have adopted the fundamental principle that the right of private property in the true owner of it is superior to that of any other, be he purchaser, carrier or warehouseman, whose right has its origin in and follows from the act of one who is tortiously in the possession of the property. It would seem to be apparent that if we are to recognize in such cases the right of the lien here claimed, and give to it the normal and necessary incidents to make it effective, we come perilously near reinstating, in effect, the repudiated doctrine of sales in market overt. The correct principle generally adhered to by the courts of last resort throughout the states of the Union is thus declared by Fletcher, J., speaking for the Supreme Court of Massachusetts, in Robinson v. Baker, 59 Mass. I37, in an opinion analyzing all the cases, English and American, our own case of King v. Richards, among them: 'If the owner loses his property, or is robbed or it, or it is sold or pledged without his consent by one who has only a . . . qualified possession of it for a specific purpose, as for . . . work to be done

56. $I d$. at 88 .

57. 4I Pa. Super. 6ro (IgIO). 
upon it, the owner can follow and reclaim it in the possession of any person howsoever innocent." "58

The Pennsylvania courts, while recognizing there may be circumstances from which an owner's consent can be reasonably implied, ${ }^{59}$ has never on the grounds of implied authority subordinated the rights of a bailor under a bailment lease to the common-law lien of a repairman. There have been ample opportunities where the courts of Pennsylvania might have exercised the doctrine of implied authority or favored the repairman. In addition to Stern $v$. Sica and Estey Co. $v$. Dick, previously mentioned, there are such cases as Banker's Commercial Security Co. v. Brennan \& Levy. ${ }^{60}$ In this case a mechanic made repairs to a truck at the request of one who was in possession thereof under a bailment lease. The bailment lease contract required the lessee to keep the truck in good order and repair and surrender the same at the expiration of the lease "in as good condition as when received by the lessee, 'ordinary wear and tear excepted." While in the possession of the lessee, it was damaged by fire, and delivered to the mechanic for repairs without the knowledge of the owner. The lessee having defaulted in payment, the owner sought by writ of replevin to repossess truck from the mechanic. The mechanic contended that the repairs made by him were extraordinary in character and inured to the benefit of the owner, and that extraordinary repairs which inure to the owner, and which are not necessitated by any negligence of the lessee, are to be borne by the owner. The Pennsylvania Superior Court held that the owner could replevy the truck. The court observed that the lessee "certainly could not have sold the truck so as to pass the owner's title, and as a general rule there is no reason why a party not the owner of property should be permitted to create a lien upon it any more than he should be permitted to sell it." 61

There is, indeed, little logic in saying that a bailor by intrusting the possession and use of a chattel to another impliedly authorizes the party to impose a lien thereon for repairs. Instead of presuming that the bailor has authorized the bailee to contract for repairs, it seems more consonant with reason to presume that the bailor has given the possession to the bailee with the understanding that the bailee shall personally incur all expenses necessary to keep the chattel in the condition it was in at the time possession was acquired. The bailee customarily bears the expense of repairs to chattels in his possession, especially if it is a bailment looking forward to an ultimate sale. The

58. Id. at $6 \mathrm{I}_{5}$.

59. Estey Co. v. Dick, 4I Pa. Super. 6ro (I9ro).

60. 75 Pa. Super. I99 (I920).

6I. Id. at 203 . 
repairs accrue to the benefit of the bailee-the eventual purchaser. The purpose of a bailment lease is to furnish security to the bailor. Is it reasonable to assume that a bailor would confer upon a bailee an authority to create a lien on the chattel paramount to his own? It is the basis of a contract of this character that nothing should be done, or permitted, by the bailee to impair the security. An act which will defeat the purpose of the transaction should not be presumed or inferred.

It has constantly been maintained that the repairman's lien will impair the bailor's security. This, however, is not always true. The repairs frequently add to the value of the chattel which is restored to the bailor, upon default of the bailee, and thereby preserves a security which might otherwise be valueless. But the bailor, not the bailee, should decide what repairs are necessary and reasonable. If expensive and unnecessary repairs are made upon the chattel, the bailor's security has been impaired if the repairman's claim is given a priority. A rule that subordinates the rights of the bailor puts into the hands of the person in possession the power to impair the security of the bailor without his consent. It is practically impossible for a person, not knowing anything about the condition of a chattel prior to repair, to determine that the repairs were necessary and reasonably priced. Such a rule would be a prolific source of fraud and spoliation of security.

The common-law lien is generally based on a contract. A fundamental principle of our property law is that no man can be divested of his property without his consent, except by due process of law. ${ }^{\mathbf{6 2}}$ This principle was the basis of the decision in Estey Co. v. Dick.

An innkeeper at common law was accorded a lien upon all goods brought into the hotel by the guest, even though the goods had been stolen from a third person. ${ }^{63}$ The innkeeper's lien was based upon the principle that he should be compensated in some way for the liability as practically an insurer for the guest's goods he was forced to assume and for the duty to serve all transients who should apply at his inn up to the limit of accommodations. ${ }^{84}$ The courts have continued to apply these principles in states where the lien of innkeeper has been given by statute, on the ground that the statutes are generally merely declara-

62. Cooperider v. Myre, 37 Ohio App. 502, I75 N. E. 235 (I930); see Estey Co. v. Dick, 4I Pa. Super. 6Io; 6I5 (I9I0); (I936) Io U. OF CIN. L. REv. 495.

63. Robins \& Co. v. Gray, [I895] 2 Q. B. Div. 50I ; Cook v. Kane \& Prentice, I3 Ore. 482 (I886); BEALE, THE LAW OF INNKEEPERS AND HOTELS (Ig06) $\$ \$ 256,26$, 262; Brown, Personal Property (I936) § II4; (1936) Io U. OF Cin. L. REv. 495. The innkeeper would not be accorded a lien, of course, if he was aware of the guest's wrongful possession.

64. Beale, The Law of InNkekfers and Hotels (I906) \$\$ 25I-252; DobIf, BaIlMIENTS AND CARRIERS (IgI4) § IOO. 
tory of the common-law rules. ${ }^{65}$ This is the Pennsylvania view. ${ }^{66}$ The innkeeer is, therefore, almost everywhere permitted to assert his lien against a conditional seller, chattel mortgagee, or bailor. ${ }^{67}$

The lien of the inkeeper is considerably broader than the other common-law liens. ${ }^{68}$ The lien of a common carrier, for example, does not extend to goods innocently received for shipment by the carrier without the consent of the true owner. ${ }^{69}$ This is so in spite of the fact that the common carrier and innkeeper have similar responsibilities; both are obliged to serve all applicants and to assume the liability of practically an insurer. A common carrier is not accorded a lien on goods transported at the instance of a conditional buyer, chattel mortgagor, or bailee. ${ }^{70}$

If a common carrier is not accorded a lien on goods carried at the instance of one rightfully in possession, but without authority to have the goods carried for the owner, then there is little reason why the artisan or repairman who acts at the instance of bailee should be given priority over the bailor. The artisan or repairman is not obligated to render services on all goods tendered and he does not assume an exceptional liability for loss of the goods. His claim for superiority is obviously not as meritorious as the demand of the common carrier for priority.

In general, the priority of legal interests is determined by the order of their creation. ${ }^{71}$. A lien which is prior in time is said to be prior in right. Accordingly, a repairman's lien should not be given precedence over a title-retaining instrument previously executed.

Eliminating the purely legalistic reasoning that might support the claims of priority of one or the other two groups of rival claimants,

65. Horace Waters \& Co. v. Gerard, I89 N. Y. 302, 82 N. E. I43 (I907) ; (I936) Io U. of CIN. I. Rev. 495.

66. Scot, Law of Bailments In Pennsylvania (I93I) I53; cf. Young v. Kimball, $23 \mathrm{~Pa}$. I93, I95 (1854).

67. Horace Waters \& Co. v. Gerard, I89 N. Y. 302, 82 N. E. I43 (I907) ; Mathews v. Victor Hotel Co., 74 Misc. 426,132 N. Y. Supp. 375 (IgII); Whiteside, Priorities Between Chattel Mortgagee or Conditional Seller and Subsequent Lienors (I925) Io CoRN. L. Q. 33I, 343. Occasionally, but rarely, statutes are found limiting the lien of the innkeeper to the property of the guest himself. Brown, Personal PropERTY (I936) \& II4.

68. Whiteside, Priorities Between Chattel Mortgagee or Conditional Seller and Subsequent Lienors (I925) to CORN. L. Q. 33I.

69. Ibid.; (Ig09) 23 HARV. I. Rev. 63; (1936) Io U. of CIN. L. Rev. 495; Savannah, F. \& W. Ry. v. Talbot, I23 Ga. 378, 5I S. E. 40I (I905) (goods delivered to carrier by wrongdoer); Gilson v. Gwinn, I07 Mass. I26 (I891) (goods delivered to carrier by bailee); Swinson v. Atchison, T. \& S. F. Ry., II7 Kan. 258, 230 Pac. I046 (I924) (goods delivered to carrier by chattel mortgagor); Corinth Engine \& Boiler Works v. Mississippi Central R. R., 95 Miss. 8I7, 49 So. 26r (I909) (goods delivered to carrier by chattel mortgagor); Owens v. Burlington, etc. Co., II S. D. I53 (I898) (goods delivered to carrier by chattel mortgagor).

70. See note 69 stupra.

7I. Jensen v. Wilcox Lumber Co., 295 I11. 294, I29 N. E. I33 (I920) (mortgagee's lien prior); General Motors Acceptance Corp. v. Sutherland, I22 Neb. 720, 24I N. W. 28 I (I932) (conditional seller's lien prior); (I928) 37 YALE L. J. 527. 
let us ask ourselves: Is it more desirable from a commercial viewpoint that the repairman be given a lien paramount to the encumbrancer who is prior in point of time, or vice versa? Let us look at the question solely from the standpoint of the business man.

A priority granted to a repairman will not only be taking the property of one man without his consent to pay the debts of another, but may so seriously impair the security of title-retaining instruments that these forms of doing business will become too precarious for practical use. Carried to its greatest possible extent, a priority given to a repairman could be the cause of a total loss to an installment seller of all that remained due to him under the security agreement. Titleretaining instruments (conditional sales, chattel mortgages, and bailment leases) should be protected and safeguarded as they have become indispensable vehicles of credit in our commercial world. Large sums of money are invested on the security of these instruments. The automobile industry, the country's largest single industry, is dependent upon the safety and security of these tools of credit.

A rule favoring the priority of repairmen would put owners of automobiles at the mercy of unscrupulous garagemen. There are doubtless many who distrust automobile mechanics. Repairmen have frequently taken unfair advantage of a bailor's or finance company's ignorance of the condition of the automobile brought to them, and have made unwarranted repairs at unreasonable prices. The bailor or finance company is not usually in a position to dispute a repairman's claim.

In a day when a majority of automobiles are purchased under a title-retaining instrument, garage proprietors cannot assert that repairs were made on the presumption that the party in possession was the rightful owner. Garage keepers are thoroughly acquainted with the extent to which automobiles are bought on the installment plan. Neither justice nor commercial necessity warrants a special protection to repairmen at the expense of an innocent third person. The repairman may always recover the costs of the repairs from the person at whose request they were made. There is apparently no justification for conferring on a repairman privileges not accorded innocent persons to whom stolen property has been sold or pledged. These are hazards to which persons in business are continually exposed.

The Pennsylvania courts, in justifying the priority that they have accorded bailors, point out that the repairman acts voluntarily and that there is nothing to prevent a repairman from demanding and receiving in advance the repair charges. ${ }^{72}$ There is, however, frequently

72. See Stern v. Sica, 66 Pa. Super. 84, 89 (IgI7) ; Estey Co. v. Dick, $4 \mathrm{I} \mathrm{Pa.}$ Super. 6I0, 6I6 (I9I0). 
present the practical difficulty of figuring in advance the costs of repairs. An automobile sometimes has to be torn almost apart before a mechanic can diagnose the mechanical trouble and determine the costs of repairs.

A Georgia case, ${ }^{73}$ in subordinating the lien of a repairman to the prior rights of a conditional seller, suggested that the remedy of the repairman was to pay off the conditional seller and then subject the chattel to a lien as against the buyer. This is in line with what Jones ${ }^{74}$ has said in respect to chattel mortgages: "When the chattels have been taken from the possession of a lienholder and sold under a chattel mortgage, the surplus after satisfying such mortgages belongs to the lienholder to the amount of his lien." There seems to be no reason why the same idea cannot be applied to bailment leases. A bailee, as well as a conditional buyer or chattel mortgagor, should be able to create a lien affecting his own interest in the property. A lien ordinarily attaches to the interest, whatever it may be, of the person who requested the labor and materials furnished.

The stand of the Pennsylvania courts against liens for repair and storage charges is in keeping with the position they have taken in all instances where rights of third persons have clashed with the interests of a bailor. The interest of the bailor in a Pennsylvania bailment lease is to be protected regardless of the hardship that is worked against innocent persons. This seems to be a policy of the courts. And since the courts have repeatedly considered the bailment lease with option to buy identical with an ordinary bailment for use until the option has been exercised, the position of the courts in this instance is probably based upon sound legal reasoning.

73. Baughman Auto Co. v. Emanuel, I37 Ga. 354, 73 S. E. 5 I I (I9II). Suggestion approved in Cache Auto Co. v. Central Garage, 63 Utah I0, 221 Pac. 862 (I923).

74. 2 Jones, Chattel Mortgages and Conditional Sales`(6th ed. 1933) § 472. 